\title{
EFFECT OF FEED RESTRICTION AND VITAMIN C SUPPLEMENTATION ON GROWTH PERFORMANCE, CARCASS CHARACTERISTICS AND SOME BLOOD PARAMETERS OF BROILER REARED UNDER HEAT STRESS
}

\author{
A.A. Desoky ${ }^{1}$ and Nancy N. Kamel ${ }^{2}$ \\ ${ }^{I}$ Department of Animal Production, Faculty of Agriculture, Cairo University, Egypt. \\ ${ }^{2}$ Department of Animal Production, National Research Center, Dokki, Giza, Egypt.
}

(Received 17/9/2018, accepted 8/11/2018)

\section{SUMMARY}

$\mathrm{P}$ roduction performance is closely related to feed intake and feed components. Heat stress has a direct effect on feed intake and can impair productivity and immunological responses. The present study was designed to investigate the effect of feed restriction and vitamin $\mathrm{C}$ supplementation on broiler performance under heat stress conditions. A total of 180 one-day old Arbor Acres chicks were randomly assigned to four experimental groups with three replicates ( 15 birds of each). The experimental chicks were fed the basal diet ad libitum (Control), fed the basal diet supplemented with $250 \mathrm{mg} / \mathrm{kg}$ vitamin C (Vit. C) ad libitum, deprived of feed for $8 \mathrm{~h} / \mathrm{day}(\mathrm{FR})$, or received the basal diet supplemented with $250 \mathrm{mg} / \mathrm{kg}$ vitamin C with feed deprivation for $8 \mathrm{~h} / \mathrm{day}(\mathrm{FR}+\mathrm{Vit}$. C). All the experimental groups were exposed to cyclic environmental heat stress of $33.5 \pm 1.5^{\circ} \mathrm{C}$ for $8 \mathrm{~h} /$ day starting from 21 to 42 days of age. The feed withdrawal was synchronized with the period of temperature elevation. Feed intake, body weight gain and feed conversion were measured on $0,21,35$ and 42 days of the experiment. At the end of the experiment, blood samples were collected for determining the $\mathrm{H} / \mathrm{L}$ ratio and quantifying some relative plasma constituents. Antibody titers of Newcastle (ND), Infectious Bronchitis (IBD) and Avian Influenza (AID) diseases were quantified after three weeks of immunization. Data revealed that feed restriction caused a significant reduction in feed intake and weight gain of broilers during the first three weeks of life. Vitamin C supplementation improved feed intake, body weight gain and feed conversion during the period from 22 to 35 days. Plasma total protein and albumin increased significantly, while transaminases (liver enzymes) activity and the $\mathrm{H} / \mathrm{L}$ ratio were reduced significantly due to different treatments when compared to the control. Antibody titers for ND and IBD significantly increased due to the different treatments as compared to the control group. The data revealed that feed restriction under thermo-neutral condition reduces the broiler growth performance. But when birds were subjected to elevated environmental temperature, feed rustication with or without vitamin $\mathrm{C}$ supplementation improved the broiler performance, with no effect on carcass characteristics, and produced a substantial improvement in immune response of heat stressed broilers. Vitamin C supplementation at $250 \mathrm{mg} / \mathrm{kg}$ can be used to alleviate the negative effects of heat stress on broiler productive and immunological responses.

Keywords: feed restriction, vitamin C, heat stress, broiler, production performance, immune response.

\section{INTRODUCTION}

Heat stress imposes a tremendous management challenge in tropical and subtropical countries. Reduction in feed intake has a direct negative effect on nutrient availability and subsequently can suppress growth of animals and poultry. Al-Batshan (2002) reported a significant reduction in both feed intake and weight gain of broilers exposed to ambient temperatures of $33 \pm 0.5^{\circ} \mathrm{C}$. The results of genetic $\times$ temperature interaction implied that the fast-growing broilers were more susceptible to heat stress as compared to the slow-growing 


\section{Desoky and Kamel}

strains. High environmental temperature (at $26.7^{\circ} \mathrm{C}$ ) lowered broiler productive performance and impaired carcass characteristics (Olanrewaju et al., 2010). Moreover, the elevation in ambient temperature to $38 \pm 1^{\circ} \mathrm{C}$ for two different broiler strains for only three hours a day caused a negative impact on oxidative stress and increased lipid peroxidation and heterophils:lymphocytes ratio (H/L) (Altan et al., 2003). A reduction in meat quality traits was also reported in cyclic or chronic heat stressed broilers (Akșit et al., 2006; Zhang et al., 2012; Zeferio et al., 2016). Tankson et al. (2001) stated that heat stress induced pale and soft exudative meat which is considered a big problem in meat quality. Heat stress can reduce productivity, and may impair the immune response by reducing the antibody production and suppressing the synthesis and function of blood lymphocytes in laying hens and broilers (Mashaly et al., 2004; Kamel et al., 2017). A reduction in antibody titers to Newcastle disease and Infectious Bural disease viruses (by 18 and 22\%, respectively) was observed in broilers exposed to cyclic heat stress at $35 \pm 1.1^{\circ} \mathrm{C} / 8 \mathrm{~h} / \mathrm{d}$ from 22 to 42 days of age (Sohail et al., 2010). Also, Al-Ghamdi (2008) found a reduction in blood antibodies (IgG and IgM) when Cobb chickens were exposed to $40^{\circ} \mathrm{C} / 3 \mathrm{~h} / \mathrm{d}$ for ten days, from 22 to 32 days of age.

Feed restriction was introduced as a management strategy to reduce the negative effect of heat stress by reducing heat increment generated with nutrient metabolism (Daghir, 2009). Naga Raja Kumari and Narendra Nath (2017) suggested that early feed restriction can be used to mediate the negative effects of heat stress through producing thermo-tolerant birds that are able to maintain high performance under hot environmental condition. Moreover, early feed restriction resulted in a positive effect on broiler immune response which was impaired by heat stress exposure (Khajavi et al., 2003). Pan et al. (2005) introduced feed restriction as an effective strategy during cold stress to reduce lipid peroxidation through improving enzymatic antioxidant activities in broilers.

Vitamin C, also called ascorbic acid, is presented as a natural antioxidant that can be used to reduce the oxidative stress imposed by heat stress. Supplementation of ascorbic acid at $250 \mathrm{mg} / \mathrm{kg}$ feed has been reported to improve feed intake, body weight gain and feed efficiency, and to enhance immune response and antioxidant status of broiler chickens (Khan et al., 2012). Abidin and Khatoon (2013) reported that vitamin C ameliorates production and immunity problems induced by heat stress such as suppressing immunity, lowering feed consumption, impairing body weight gain, inducing oxidative stress, increasing rectal temperature and increasing mortality in birds. Al-Ghamdi (2008) suggested that the alteration in plasma vitamin $\mathrm{C}$ level can be used as a heat stress indicator in broiler chickens. He found a significant reduction in plasma ascorbic acid in broilers exposed to $40^{\circ} \mathrm{C}$ for three hours a day for ten days starting from day 22 of age. McKee et al. (1997) reported that ascorbic acid supplementation has the ability to influence body energy stores in favor of improving productivity when feed restriction lead to a reduction in the energy consumption of broilers. Sahin et al. (2009) recommended a combination of vitamins C and E supplementation (500 $\mathrm{mg}$ of each $1 \mathrm{~kg}$ of diet) to the diet of quail to improve egg production and heat shock protein synthesis during heat stress.

The present study aimed to investigate the effect of feed restriction and vitamin $\mathrm{C}$ supplementation on the productive performance, carcass characteristics, blood constituents and immune response of broiler chickens reared under cyclic heat stress conditions.

\section{MATERIALS AND METHODS}

\section{Experimental design:}

A total of 180 Arbor Acres broiler chicks at one-day old were divided to four experimental groups and three replicates (15 chicks each) in each group. The experimental birds were offered the basal diet ad libitum (Control), fed the basal diet supplemented with $250 \mathrm{mg} / \mathrm{kg}$ vitamin C (Vit. C) ad libitum, deprived of feeding for $8 \mathrm{~h}$ a day and then freely fed the basal diet (FR), or given the basal diet supplemented with $250 \mathrm{mg} / \mathrm{kg}$ vitamin $\mathrm{C}$ with feed withdrawal for $8 \mathrm{~h}$ a day (FR+Vit. C). Starting from day 21 of the experiment, all groups were subjected to cyclic heat stress $\left(33.5 \pm 1.5^{\circ} \mathrm{C}\right)$ for $8 \mathrm{~h}$ per day. The time of feed withdrawal, for FR and $\mathrm{FR}+\mathrm{Vit}$. $\mathrm{C}$ groups was synchronized with the time of temperature elevation during the day. The experimental 
chicks were reared in environmentally controlled floor pens with a light schedule of $23 \mathrm{~h} \mathrm{~L}: 1 \mathrm{~h}$ D. The basal diets were formulated to cover the requirement of birds according to NRC (1994), and contained 23.00\% CP and 2,986 kcal $/ \mathrm{kg}$ of ME from hatching to 3 weeks old and $21.24 \% \mathrm{CP}$ and 3,179 kcal $/ \mathrm{kg}$ of ME from 3 to 6 weeks of age (Table 1).

Table (1): Composition and calculated analysis of the basal starter and grower diets.

\begin{tabular}{lcc}
\hline Ingredient & $\begin{array}{c}\text { Starter } \\
(0-3 \text { Weeks })\end{array}$ & $\begin{array}{c}\text { Grower } \\
(3-6 \text { Weeks })\end{array}$ \\
\hline Yellow corn & 54.50 & 57.50 \\
Soybean meal & 33.00 & 28.00 \\
Corn gluten meal & 6.20 & 6.50 \\
Soybean oil & 2.00 & 4.00 \\
Dicalcium phosphate & 1.80 & 1.60 \\
Calcium carbonate & 1.60 & 1.50 \\
Salt (NaCl) & 0.20 & 0.20 \\
DL-Methionine & 0.20 & 0.20 \\
L-Lysine & 0.20 & 0.20 \\
Premix* & 0.30 & 0.30 \\
Calculated Analysis & & \\
Crude Protein, \% & 23.00 & 21.24 \\
ME, Kcal/kg & 2,986 & 3,179 \\
Calcium, \% & 1.02 & 0.93 \\
Phosphorus, \% & 0.50 & 0.45 \\
Lysine, \% & 1.29 & 1.17 \\
Methionine \& Cysteine, \% & 0.95 & 0.91 \\
\hline
\end{tabular}

*Each $3 \mathrm{Kg}$ of the premix contains: Vitamins: A, 12,000,000 IU; Vit. D, 2,000,000 IU; Vit. E, 10,000 mg; Vit. K, 2000 mg; Vit. B1, 1000 mg; Vit. B2, 5000 mg; Vit. B6, 1500 mg; Vit. B12, 10 mg; Biotin, 50 mg; Choline chloride, 250000 mg; Pantothenic acid, 10,000 mg; Nicotinic acid, $30000 \mathrm{mg}$; Folic acid, $1000 \mathrm{mg}$; Minerals: Mn, 60,000 mg; Zn, $50000 \mathrm{mg}$; $\mathrm{Fe}, 30000 \mathrm{mg} ; \mathrm{Cu}, 10,000 \mathrm{mg} ; \mathrm{I}, 1000 \mathrm{mg} ; \mathrm{Se}, 100 \mathrm{mg}$ and $\mathrm{Co}, 100 \mathrm{mg}$.

ME: Metabolizable energy.

\section{Production and physiological parameters:}

Body weights were determined at hatch, before applying the heat treatment (day 21), and at 35 and 42 days of age. Feed consumption was measured from 0 to 21, 22 to 35 and from 36 to 42 days of age. Feed conversion was calculated for each group at different experimental periods. Nine birds were randomly taken at the end of the experiment from each group ( 3 birds/ replicate) for measuring rectal temperature by inserting a digital thermometer into the cloaca of each chick for one minute.

Broilers were slaughtered at 42 days of age after $8 \mathrm{~h}$ of feed withdrawal ( 3 birds/ replicate). Carcasses were chilled and weighed while the edible organs (gizzard, heart and liver) were separated and weighed. The abdominal fat and total carcass fat (the summation of abdominal, gizzard and neck fats) were separated and weighed. Carcass, giblets, abdominal fat and total carcass fat were expressed as percentages of body weight at slaughter.

At the end of the experiment, blood samples were collected at slaughter in heparinized tubes, from nine birds of each group (3 birds/ replicate), and plasma was separated and stored at $-20{ }^{\circ} \mathrm{C}$ until further analysis. Concentrations of total protein, albumin, cholesterol, triglycerides, and activity of transaminases (AST and ALT) were measured in plasma using kits (Salucea, Haansberg, Netherlands). The heterophils:lymphocytes (H/L) ratio was determined in whole blood using Hema-3 stain (cat\# 22-122911, Fisher scientific, USA), according to Zhang et al. (2009). Tibia ash percentage determination was performed according to AOAC 
International (2005) where tibia pieces were collected, defatted, and ashed at $600^{\circ} \mathrm{C}$ for $16 \mathrm{~h}$ to determine ash percentage. Total $\mathrm{P}$ in the samples was determined according to Onyango et al. (2003) using a colorimetric method. Briefly, samples were ashed and boiled in acid to dissolve all $\mathrm{P}$. The concentration of $\mathrm{P}$ in the supernatant was determined using a kit. Ammonium molybdate was added to the supernatant to form phosphomolybdate, which was then reduced to form a blue phosphomolybdenum complex. Color intensity of the complex was proportional to the $\mathrm{P}$ concentration and the latter was determined with a spectrophotometer using absorption at $620 \mathrm{~nm}$. Calcium was determined by flame atomic absorption spectroscopy.

\section{Immune response:}

Birds were vaccinated against Newcastle disease (ND) and Infectious Bronchitis disease (IBD) at day 6. The birds were administered with another dose of vaccines against ND and IBD at day 21. At 12 days of age, birds were immunized by vaccines against Avian Influenza disease (AID). Nine blood samples were collected from each group ( 3 birds/replicate) at the end of the experiment. Commercial ELISA kits were used for detection of antibodies against nucleoprotein and matrix antigen of IBD. The other two antibody titers of ND and AID were determined by hemagglutination-inhibition test as described by Khan et al. (2014).

\section{Statistical analysis:}

Data were statistically analyzed by one-way analysis of variance for treatment effect, using the general linear model (GLM) procedure of SAS (2006). When the model was significant, Duncan's test was used to separate treatment means at $\mathrm{P} \leq 0.05$ (Duncan, 1955).

\section{RESULTS AND DISCUSSION}

\section{Productive performance:}

The productive performance parameters and body temperature of broiler chickens supplemented with vitamin $\mathrm{C}$ and/or subjected to $8 \mathrm{~h}$ of feed deprivation under different periods of thermo-neutral and heat stress conditions are presented in Table 2. The results obtained from the first experimental period (1-21 d) show a significant negative effect of feed restriction on body weight gain (BWG) and feed intake for FR and FR+Vit. C groups.

Table (2): Broiler performance under feed restriction (FR) concurrent with or without vitamin C supplementation (Vit. C) and exposed to heat stress.

\begin{tabular}{lcccc}
\hline Performance traits & Control & Vit. C & FR & FR+Vit. C \\
\hline Initial weight, g & $40 \pm 0.1$ & $43 \pm 0.1$ & $43 \pm 0.2$ & $43 \pm 0.1$ \\
Final weight, kg & $2.46 \pm 0.04^{\mathrm{c}}$ & $2.63 \pm 0.04^{\mathrm{a}}$ & $2.51 \pm 0.04^{\mathrm{bc}}$ & $2.62 \pm 0.04^{\mathrm{ab}}$ \\
Weight gain, kg & & & & \\
1-21d & $0.779 \pm 0.01^{\mathrm{b}}$ & $0.796 \pm 0.01^{\mathrm{a}}$ & $0.755 \pm 0.01^{\mathrm{d}}$ & $0.770 \pm 0.01^{\mathrm{c}}$ \\
22-35d & $0.940 \pm 0.01^{\mathrm{b}}$ & $1.06 \pm 0.02^{\mathrm{a}}$ & $1.04 \pm 0.02^{\mathrm{a}}$ & $1.07 \pm 0.02^{\mathrm{a}}$ \\
36-42d & $0.700 \pm 0.02$ & $0.736 \pm 0.02$ & $0.678 \pm 0.04$ & $0.734 \pm 0.04$ \\
1-42 d & $2.42 \pm 0.04^{\mathrm{c}}$ & $2.59 \pm 0.04^{\mathrm{a}}$ & $2.47 \pm 0.04^{\mathrm{bc}}$ & $2.57 \pm 0.04^{\mathrm{ab}}$ \\
Feed intake, g/bird/d & & & & \\
1-21d & $51.21 \pm 0.05^{\mathrm{a}}$ & $51.91 \pm 0.25^{\mathrm{a}}$ & $49.26 \pm 0.29^{\mathrm{b}}$ & $49.85 \pm 0.19^{\mathrm{b}}$ \\
22-35d & $120.19 \pm 0.17^{\mathrm{d}}$ & $125.21 \pm 0.32^{\mathrm{b}}$ & $122.13 \pm 0.39^{\mathrm{c}}$ & $126.86 \pm 0.39^{\mathrm{a}}$ \\
36-42d & $215.94 \pm 0.20^{\mathrm{a}}$ & $208.13 \pm 0.36^{\mathrm{b}}$ & $195.65 \pm 0.40^{\mathrm{d}}$ & $205.52 \pm 0.23^{\mathrm{c}}$ \\
Feed conversion & & & & \\
1-21d & $1.38 \pm 0.001^{\mathrm{a}}$ & $1.37 \pm 0.006^{\mathrm{ab}}$ & $1.37 \pm 0.006^{\mathrm{ab}}$ & $1.36 \pm 0.006^{\mathrm{b}}$ \\
22-35d & $1.79 \pm 0.003^{\mathrm{a}}$ & $1.66 \pm 0.006^{\mathrm{b}}$ & $1.65 \pm 0.006^{\mathrm{b}}$ & $1.66 \pm 0.006^{\mathrm{b}}$ \\
36-42d & $2.16 \pm 0.007^{\mathrm{a}}$ & $1.98 \pm 0.003^{\mathrm{c}}$ & $2.02 \pm 0.006^{\mathrm{b}}$ & $1.96 \pm 0.002^{\mathrm{d}}$ \\
Rectal temperature, ${ }^{\circ} \mathrm{C}$ & $41.47 \pm 0.14^{\mathrm{a}}$ & $41.43 \pm 0.14^{\mathrm{a}}$ & $41.07 \pm 0.07^{\mathrm{b}}$ & $41.04 \pm 0.08^{\mathrm{b}}$ \\
\hline a,b,c,d Means in the same row with no common superscript differ significantly $(P \leq 0.05)$. &
\end{tabular}


Egyptian J. Nutrition and Feeds (2018)

It has been reported that feed restriction with time limiting for broiler chickens from day 8 to day 16 of age resulted in a reduction in body weight gain at the end of the restriction period (Demir et al., 2004; Butzen et al., 2013). Liew et al. (2003) reported that feed restriction caused a reduction in body weight of broilers subjected to $36{ }^{\circ} \mathrm{C}$ from 2 to 28 days of age, but then growth compensation was observed at 35 days of age. The positive effect of feed restriction on BWG and feed intake in this study began to appear when birds were subjected to high ambient temperature during the period from the day 22 to the day 35 of the experiment compared to the control group. The improvement in BWG of broilers did not continue during the last period from 36 to 42 days of age, which implies an adaptation of the birds in the control group to the cyclic heat stress imposed from day 21 of age. Altan et al. (2000) suggested that low-weight broiler strains can be adapted to heat stress, with no negative effect on growth rate, when exposed to early high environmental temperature. Similar reductions in feed intake and body weight were reported in broilers subjected to cyclic heat stress $\left(31 \pm 1\right.$ or $\left.36 \pm 1{ }^{\circ} \mathrm{C} / 10 \mathrm{~h} / \mathrm{d}\right)$ applied from 35 to 42 days of age (Quinteiro-Filho et al., 2010). Laganá et al. (2007) reported that lower feed intake is the main reason for the impaired broiler performance caused by high environmental temperature. Thus, the increase in feed intake of broilers during the second period of this study was reflected on both positive BWG and feed conversion ratio.

Vitamin $\mathrm{C}$ supplementation to non-stressed broilers at the first 21 days of life positively modulate the production performance. Elagib and Omer (2012) reported an improvement in feed intake, weight gain and feed conversion with ascorbic acid supplementation at 150 or $350 \mathrm{mg} / \mathrm{kg}$ diet to heat stressed broilers. Chand et al. (2014) found that ascorbic acid supplementation increased feed intake, body weight gain and improved feed conversion of broilers reared under cyclic heat stress from day 21 to day 35 of age. Moreover, similar results were reported with negative performance of broilers when they were exposed to cyclic $\left(21-30 \pm 2{ }^{\circ} \mathrm{C}\right)$ heat stress as compared to their thermo-neutral control at $25 \pm 2{ }^{\circ} \mathrm{C}$ (Abu-Dieyeh, 2006). But when feed restriction was combined with vitamin $\mathrm{C}$ supplementation, at the present study an obvious improvement in performance was obtained.

Feed conversion was improved during the first period (1-21 days) in FR+Vit. C group compared to the control. Under heat stress, from day 22 to day 42, feed conversion ratios for FR+Vit C, Vit. C and FR groups were significantly improved. The results of feed conversion reflect the changes in both BWG and feed intake. It was reported that vitamin C supplementation to heat-stressed quail at $500 \mathrm{mg} / \mathrm{kg}$ from the seventh day of age improved body weight gain and feed conversion ratio (Mehmet et al., 2004).

Rectal temperature decreased significantly by feed restriction with or without vitamin C supplementation. High ambient temperatures have been reported to cause a significant elevation in rectal temperature in six weeks old broilers in a temperature-dependent manner with the gradual increase of ambient temperature from 32 to $38^{\circ} \mathrm{C}$ (Tan et al., 2010). Francis et al. (1991) reported that food withdrawal two hours before temperature elevation and throughout the period of high ambient temperature significantly reduced rectal temperature of broilers.

\section{Carcass and tibia bone characteristics:}

Carcass characteristics percentages and tibia ash, calcium and phosphorus are presented in Table 3. Carcass, giblets and dressing percentages did not show any differences due to treatments. Meanwhile, both abdominal fat and total fat percentages were significantly decreased in Vit. C, FR and FR+Vit. C groups compared to the control group. The non-significant differences in carcass and giblet percentages can imply a compensatory effect of body weight gain in the feed restricted groups. Afsharmanesh et al. (2016) stated that birds subjected to feed restriction achieved growth compensation and were able to attain normal market body weight at 42 days of age. Zhan et al. (2007) reported a decrease in abdominal fat in broilers that were deprived of feed for $4 \mathrm{~h}$ per day from hatching to 21 days of age. They suggested that early feed restriction might have induced metabolic programming in chicks leading to changes in carcass composition. Zeferino $e t$ al. (2016) found no interaction effects between ambient temperature and vitamins $\mathrm{C}$ and $\mathrm{E}$ supplementation to heat stressed broilers on carcass or giblet percentages.

Tibia calcium percentage increased significantly in the FR and FR+Vit. C groups, suggesting a shift in calcium metabolism in feed restricted groups. Meanwhile, tibia ash and tibia phosphorus percentages did not differ due to treatments compared to the control. 
Table (3): Carcass and tibia bone characteristics \% of broiler chickens subjected to feed restriction (FR) concurrent with or without vitamin $\mathrm{C}$ (Vit. C) and exposed to heat stress.

\begin{tabular}{lcccc}
\hline Characteristics \% & Control & Vit. C & FR & FR+Vit. C \\
\hline Carcass & $73.49 \pm 0.07$ & $73.52 \pm 0.06$ & $73.62 \pm 0.08$ & $73.68 \pm 0.05$ \\
Giblets & $4.62 \pm 0.09$ & $4.84 \pm 0.20$ & $4.62 \pm 0.09$ & $4.86 \pm 0.20$ \\
Dressing & $78.12 \pm 0.13$ & $78.36 \pm 0.22$ & $78.24 \pm 0.18$ & $78.54 \pm 0.22$ \\
Abdominal fat & $1.96 \pm 0.05^{\mathrm{a}}$ & $1.64 \pm 0.10^{\mathrm{b}}$ & $1.52 \pm 0.11^{\mathrm{b}}$ & $1.50 \pm 0.07^{\mathrm{b}}$ \\
Total carcass fat & $8.76 \pm 0.24^{\mathrm{a}}$ & $7.26 \pm 0.22^{\mathrm{b}}$ & $6.52 \pm 0.10^{\mathrm{c}}$ & $6.44 \pm 0.10^{\mathrm{c}}$ \\
Tibia ash* & $52.15 \pm 0.79$ & $53.12 \pm 0.82$ & $53.32 \pm 1.13$ & $53.25 \pm 1.00$ \\
Tibia Calcium** & $30.16 \pm 0.35^{\mathrm{b}}$ & $30.88 \pm 0.40^{\mathrm{ab}}$ & $32.11 \pm 0.74^{\mathrm{a}}$ & $32.26 \pm 0.81^{\mathrm{a}}$ \\
Tibia Phosphorus** & $16.42 \pm 0.21$ & $16.82 \pm 0.29$ & $17.24 \pm 0.47$ & $17.34 \pm 0.55$ \\
\hline a,b,c Means in the same row with no common superscript differ significantly $(P \unlhd 0.05)$. &
\end{tabular}

*Total carcass fat: the summation of abdominal, gizzard and neck fats.

**Tibia calcium and phosphorus was calculated as a percentage from ash.

\section{Blood parameters:}

Blood parameters, of broiler chickens subjected to feed restriction (FR) and/or supplemented with vitamin $\mathrm{C}$ (Vit. C) are presented in Table 4. Plasma total protein and albumin significantly increased with FR and Vit. C supplementation and their combination as compared to the control group. Plasma cholesterol and triglycerides levels did not differ due to the treatments, however, a tendency of reduction was observed. Activity of transaminases (AST and ALT) showed a significant reduction due to the treatments as compared to the control group. Lin et al. (2006) reported that acute heat exposure $\left(32{ }^{\circ} \mathrm{C}\right.$ for $\left.6 \mathrm{~h}\right)$ of five weeks old broiler chickens induces oxidative stress which causes a serious injury in the liver. They also linked between elevated body temperature and the induction of serious metabolic changes leading to the induction of oxidative stress that negatively affects liver activity. At the present study, a significant decrease in body temperature was noticed (Table 2) in FR and FR+Vit. C groups which can explain the significant reduction in liver enzymes activity (ALT and AST) observed for these groups. The ratio of H/L was significantly reduced in the FR and/or Vit. C supplementation groups compared to the control group. The results showed that both feed restriction and vitamin $\mathrm{C}$ supplementation or their combination have positive effect on alleviating the stress imposed by high environmental temperature.

Table (4): Blood parameters of broiler chickens subjected to feed restriction (FR) concurrent with or without vitamin C (Vit. C) and exposed to heat stress.

\begin{tabular}{lcccr}
\hline Blood parameters & Control & Vit. C & FR & FR+Vit. C \\
\hline Total protein, g/dl & $5.08 \pm 0.10^{\mathrm{c}}$ & $5.75 \pm 0.13^{\mathrm{b}}$ & $5.86 \pm 0.14^{\mathrm{ab}}$ & $6.22 \pm 0.14^{\mathrm{a}}$ \\
Albumin, g/dl & $2.81 \pm 0.11^{\mathrm{b}}$ & $3.17 \pm 0.13^{\mathrm{a}}$ & $3.22 \pm 0.13^{\mathrm{a}}$ & $3.42 \pm 0.11^{\mathrm{a}}$ \\
Globulin, g/dl & $2.27 \pm 0.19^{\mathrm{b}}$ & $2.58 \pm 0.17^{\mathrm{ab}}$ & $2.64 \pm 0.16^{\mathrm{ab}}$ & $2.80 \pm 0.15^{\mathrm{a}}$ \\
Cholesterol, mg/dl & $142.17 \pm 8.97$ & $128.12 \pm 9.15$ & $122.14 \pm 9.29$ & $119.21 \pm 8.81$ \\
Triglycerides, mg/dl & $152.24 \pm 10.15$ & $138.16 \pm 8.03$ & $134.86 \pm 8.22$ & $128.14 \pm 8.05$ \\
ALT, U/l & $22.16 \pm 1.17^{\mathrm{a}}$ & $18.46 \pm 1.14^{\mathrm{b}}$ & $18.68 \pm 0.97^{\mathrm{b}}$ & $17.51 \pm 1.08^{\mathrm{b}}$ \\
AST, U/l & $42.51 \pm 1.36^{\mathrm{a}}$ & $37.22 \pm 1.35^{\mathrm{b}}$ & $35.40 \pm 1.37^{\mathrm{b}}$ & $35.21 \pm 1.30^{\mathrm{b}}$ \\
H/L ratio & $0.58 \pm 0.01^{\mathrm{a}}$ & $0.48 \pm 0.01^{\mathrm{b}}$ & $0.46 \pm 0.011^{\mathrm{bc}}$ & $0.44 \pm 0.011^{\mathrm{c}}$ \\
\hline a,b,c Means in the same row with no common superscript differ significantly $(P \unlhd 0.05)$. &
\end{tabular}




\section{Immune response:}

The antibody titers of different immunized viral diseases are presented in Fig. 1. The antibody titers of ND and IBD significantly increased due to feed restriction and/or vitamin C supplementation. Meanwhile, there was no change in the AID antibody titer due to treatments compared to the control.

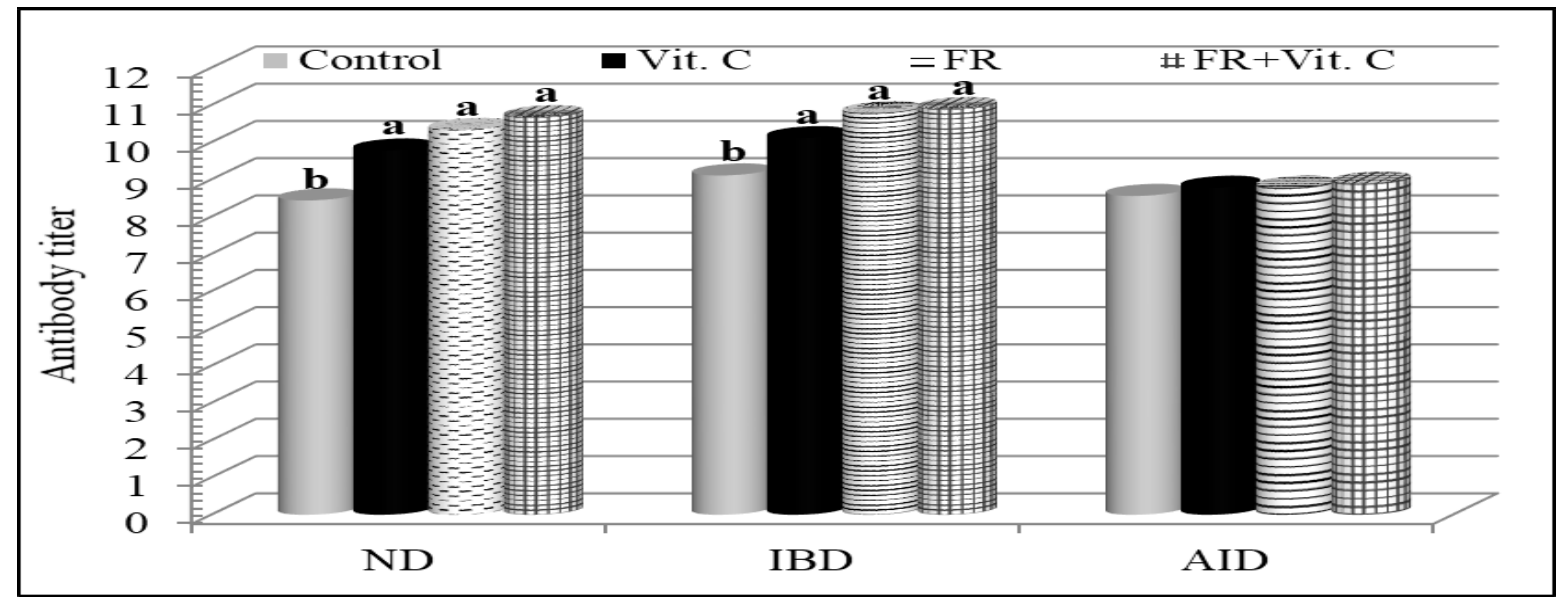

Figure (1): Blood antibody titer of Newcastle (ND), Infectious Bronchitis (IBD) and Avian Influenza (AID) in broilers subjected to feed restriction (FR) concurrent with or without vitamin C (Vit. C) and exposed to heat stress.

Quinteiro-Filho et al. (2010) reported a reduction in the relative weights of bursa of Fabricius, thymus, and spleen in broilers reared under cyclic heat stress $\left(31 \pm 1\right.$ or $\left.36 \pm 1{ }^{\circ} \mathrm{C} / 10 \mathrm{~h} / \mathrm{day}\right)$. Ascorbic acid supplementation with different levels $(150,350$ and $550 \mathrm{mg} / \mathrm{kg})$ to heat stressed broilers caused a significant direct increase in the antibodies against ND (Elagib and Omer, 2012). Chand et al. (2014) also, reported a significant increase in antibody titers of ND and IBD in cyclic heat stressed broilers fed ascorbic acid at 300 $\mathrm{mg} / \mathrm{kg}$ diet for three weeks starting at 21 days of age. On the other hand, Liew et al. (2003) observed a tendency of increasing the antibody titer to infectious bursal disease of broilers reared under cyclic heat stress and subjected to feed restriction as compared to the control group.

\section{CONCLUSION}

The present study revealed that feed restriction to broilers reared under thermo-neutral condition reduced the broiler performance. When birds were subjected to elevated environmental temperature and feed rustication with or without vitamin $\mathrm{C}$ supplementation, their performance and immune response were improved, with no effect on carcass characteristics. Vitamin C supplementation also had a positive effect on broiler production performance and immune response during heat stress which confirmed the role of vitamin $\mathrm{C}$ as anti-stress agent.

\section{REFERENCES}

Abidin, Z. and A. Khatoon (2013). Heat stress in poultry and the beneficial effects of ascorbic acid (vitamin C) supplementation during periods of heat stress. World's Poultry Science Journal, 69 (1): 135-152. 


\section{Desoky and Kamel}

Abu-Dieyeh, Z. H. M. (2006). Effect of chronic heat stress and long-term feed restriction on broiler performance. International Journal of Poultry Science, 5(2): 185-190.

Afsharmanesh, M.; M. Lotfi and Z. Mehdipour (2016). Effects of wet feeding and early feed restriction on blood parameters and growth performance of broiler chickens. Animal Nutrition, 2(3): 168-172.

Akşit, M.; S. Yalçin; S. Özkan; K. Metin and D. Özdemir (2006). Effects of temperature during rearing and crating on stress parameters and meat quality of broilers. Poultry Science, 85(11): 1867-1874.

Al-Batshan, H. A. (2002). Performance and heat tolerance of broilers as affected by genotype and high ambient temperature. Asian-Aust. Journal of Animal Science, 15(10): 1502-1506.

Al-Ghamdi, Z. H. (2008). Effects of commutative heat stress on immunoresponses in broiler chickens reared in closed system. International Journal of Poultry Science, 7(10): 964-968.

Altan, Ö.; A. Altan; I. Oguz; A. Pabuçcuoglu and S. Konyalioglu (2000). Effects of heat stress on growth, some blood variables and lipid oxidation in broilers exposed to high temperature at an early age. British Poultry Science, 41(4): 489-493.

Altan, Ö.; A. Pabuçcuoğlu; A. Altan; S. Konyalioğlu and O. H. Bayraktar (2003). Effect of heat stress on oxidative stress, lipid peroxidation and some stress parameters in broilers. British Poultry Science, 44(4): $545-550$.

AOAC International (2005). Official Methods of Analysis of the Association of Official Analytical Chemists. $18^{\text {th }}$ ed. AOAC Int., Arlington, VA.

Butzen, F. M.; A. M. L. Ribeiro; M. M. Vieira; A. M. Kessler; J. C. Dadalt and M. P. Della (2013). Early feed restriction in broilers. I-Performance, body fraction weights, and meat quality. The Journal of Applied Poultry Research, 22(2): 251-259.

Chand, N.; S. Naz; A. Khan; S. Khan and R. U. Khan (2014). Performance traits and immune response of broiler chicks treated with zinc and ascorbic acid supplementation during cyclic heat stress. International Journal of Biometeorology, 58(10): 2153-2157.

Daghir, N. J. (2009). Nutritional strategies to reduce heat stress in broilers and broiler breeders. Lohmann Information, 44(1): 6-15.

Demir, E.; S. Sarica; A. Sekeroglu; M. A. Ozcan and Y. Seker (2004). Effects of early and late feed restriction or feed withdrawal on growth performance, ascites and blood constituents of broiler chickens. Acta Agriculturae Scandinavica, Section A — Animal Science, 54(3): 152-158.

Duncan, D.B. (1955). Multiple range and multiple F-tests. Biometrics, 11:1-42.

Elagib, H. A. A. and H. M. Omer (2012). Effect of dietary ascorbic acid on performance and immune response of heat stressed broiler chicks. Pakistan Journal of Nutrition, 11(3): 216-220.

Francis, C. A.; M. G. Macleod and J. E. M. Anderson (1991). Alleviation of acute heat stress by food withdrawal or darkness. British Poultry Science, 32(1): 219-225.

Kamel, N. N.; A. M. H. Ahmed; G. M. K. Mehaisen; M. M. Mashaly and A. O. Abass (2017). Depression of leukocyte protein synthesis, immune function and growth performance induced by high environmental temperature in broiler chickens. International Journal of Biometeorology, 61(9): 1637-1645.

Khajavi, M.; S. Rahimi; Z. M. Hassan; M. A. Kamali and T. Mousavi (2003). Effect of feed restriction early in life on humoral and cellular immunity of two commercial broiler strains under heat stress conditions. British Poultry Science, 44(3): 490-497.

Khan, R. U.; S. Naz; Z. Nikousefat; M. Selvaggi; V. Laudadio and V. Tufarelli (2012). Effect of ascorbic acid in heat-stressed poultry. World's Poultry Science Journal, 68(3): 477-490. 
Khan, R. U.; Z. U. Rahman; I. Javed and F. Muhammad (2014). Effect of vitamins, protein level and probiotics on immune response of moulted male broiler breeders. Journal of Animal Physiology and Animal Nutrition, 98(4): 620-627.

Laganá, C.; A. M. L. Ribeiro; A. M. Kessler; L. R. Kratz and C. C. Pinheiro (2007). Effects of the reduction of dietary heat increment on the performance, carcass yield, and diet digestibility of broilers submitted to heat stress. Brazilian Journal of Poultry Science, 9(1): 45-51.

Liew, P. K.; I. Zulkifli; M. Hair-Bejo; A. R. Omar and D. A. Israf (2003). Effects of early age feed restriction and heat conditioning on heat shock protein 70 expression, resistance to infectious bursal disease, and growth in male broiler chickens subjected to heat stress. Poultry Science, 82(12): 1879-1885.

Lin, H., E. Decuypere and J. Buyse (2006). Acute heat stress induces oxidative stress in broiler chickens. Comparative Biochemistry and Physiology Part A: Molecular and Integrative Physiology, 144(1): 11-17.

Mashaly, M. M.; G. L. Hendricks; M. A. Kalama; A. E. Gehad; A. O. Abbas and P. H. Patterson (2004). Effect of heat stress on production parameters and immune responses of commercial laying hens. Poultry Science, 83(6): 889-894.

McKee, J. S.; P. C. Harrison and G. L. Riskowski (1997). Effects of supplemental ascorbic acid on the energy conversion of broiler chicks during heat stress and feed withdrawal. Poultry Science, 76(9): 12781286.

Mehmet, A.; Y. Muğdat, and K. Oktay (2004). Effect of ascorbic acid on the performance and some blood parameters of Japanese quails reared under hot climate conditions. Turkish Journal of Veterinary and Animal Sciences, 29: 829-833.

Naga Raja Kumari, K. and D. Narendra Nath (2017). Ameliorative measures to counter heat stress in poultry. World's Poultry Science Journal, 74(1): 117-130.

NRC (1994). Nutrient Requirements of Poultry. 9th rev. ed. National Academy Press, Washington, DC, USA.

Olanrewaju, H. A.; J. L. Purswell; S. D. Collier and S. L. Branton (2010). Effect of ambient temperature and light intensity on growth performance and carcass characteristics of heavy broiler chickens at 56 days of age. International Journal of Poultry Science, 9(8): 720-725.

Onyango, E. M.; P. Y. Hester; R. Stroshine and O. Adeola (2003). Bone densitometry as an indicator of percentage tibia ash in broiler chicks fed varying dietary calcium and phosphorus levels. Poultry Science, 82(11): 1787-1791.

Pan, J. Q.; X. Tan; J. C. Li; W. D. Sun and X. L. Wang (2005). Effects of early feed restriction and cold temperature on lipid peroxidation, pulmonary vascular remodelling and ascites morbidity in broilers under normal and cold temperature. British Poultry Science, 46(3): 374-381.

Quinteiro-Filho, W. M.; A. Ribeiro; V. Ferraz-de-Paula; M. L. Pinheiro; M. Sakai; L. R. M. Sá; A. J. P. Ferreira and J. Palermo-Neto (2010). Heat stress impairs performance parameters, induces intestinal injury, and decreases macrophage activity in broiler chickens. Poultry Science, 89(9):1905-1914.

Sahin, N.; M. Tuzcu; C. Orhan; M. Onderci; Y. Eroksuz and K. Sahin (2009). The effects of vitamin C and E supplementation on heat shock protein 70 response of ovary and brain in heat-stressed quail. British Poultry Science, 50(2): 259-265.

SAS (2006). SAS/STAT ${ }^{\circledR} 9.1$ User's Guide. SAS Institute Inc., Cary, NC, USA.

Sohail, M. U.; A. Ijaz; M. S. Yousaf; K. Ashraf; H. Zaneb; M. Aleem and H. Rehman (2010). Alleviation of cyclic heat stress in broilers by dietary supplementation of mannan-oligosaccharide and Lactobacillusbased probiotic: Dynamics of cortisol, thyroid hormones, cholesterol, C-reactive protein, and humoral immunity. Poultry Science, 89(9): 1934-1938. 


\title{
Desoky and Kamel
}

Tan, G. Y.; L. Yang; Y. Q. Fu; J. H. Feng and M. H. Zhang (2010). Effects of different acute high ambient temperatures on function of hepatic mitochondrial respiration, antioxidative enzymes, and oxidative injury in broiler chickens. Poultry Science, 89(1): 115-122.

Tankson, J. D.; Y. Vizzier-Thaxton; J. P. Thaxton; J. D. May and J. A. Cameron (2001). Stress and nutritional quality of broilers. Poultry Science, 80(9): 1384-1389.

Zeferino, C. P.; C. M. Komiyama; V. C. Pelícia; V. B. Fascina; M. M. Aoyagi; L. L. Coutinho; J. R. Sartori and A. S. Moura (2016). Carcass and meat quality traits of chickens fed diets concurrently supplemented with vitamins $\mathrm{C}$ and $\mathrm{E}$ under constant heat stress. Animal, 10(1): 163-171.

Zhan, X. A.; M. Wang; H. Ren; R. Q. Zhao; J. X. Li and Z. L. Tan (2007). Effect of early feed restriction on metabolic programming and compensatory growth in broiler chickens. Poultry Science, 86(4): 654-660.

Zhang, L.; H. Y. Yue; H. J. Zhang; L. Xu, S. G. Wu; H. J. Yan; Y. S. Gong and G. H. Qi (2009). Transport stress in broilers: I. blood metabolism, glycolytic potential, and meat quality. Poultry Science, 88: 20333041.

Zhang, Z. Y.; G. Q. Jia; J. J. Zuo; Y. Zhang; J. Lei; L. Ren and D. Y. Feng (2012). Effects of constant and cyclic heat stress on muscle metabolism and meat quality of broiler breast fillet and thigh meat. Poultry Science, 91(11): 2931-2937.

\section{تأثير تحديد الغذاء وإضافة فيتامين ج على الأداء الإنتاجى وصفات الذبيحة وبعض قياسات الام لاجاج التسمين

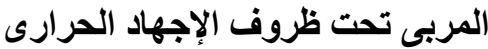

\author{
عادل عبد المنعم دسوقى 1 و نانسى نبيل كامل2

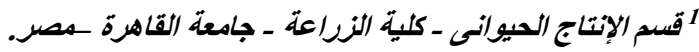 \\ 2ققم الإتتاج الحيوانس ـالمركز القومى للبحوث ـ الدقى - الجبيزة - مصر.
}

يرتبط الأداء الإتتاجى بصفة وثيقة بكل من المأكول من الغذاء وتركيب الغذاء. وبما أن الإجهاد الحرارى يؤثر بشكل مباشر على المأكول

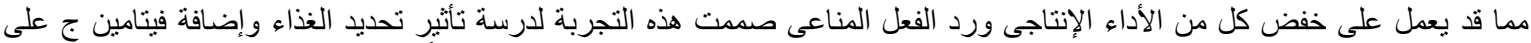

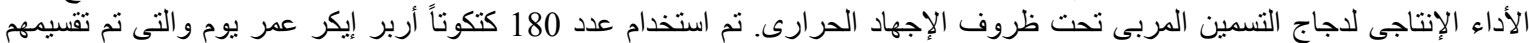

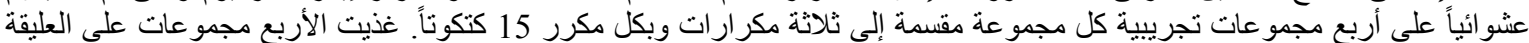

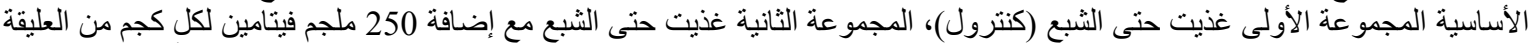

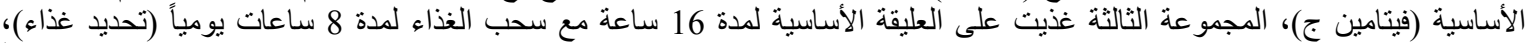

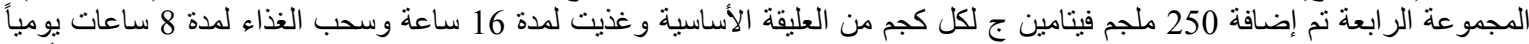

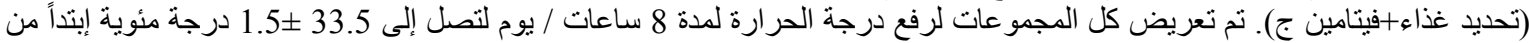

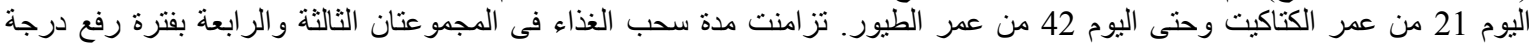

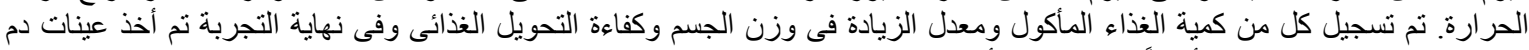

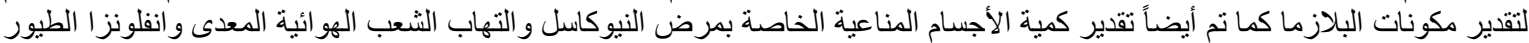

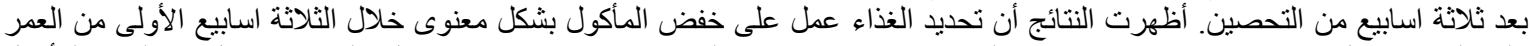

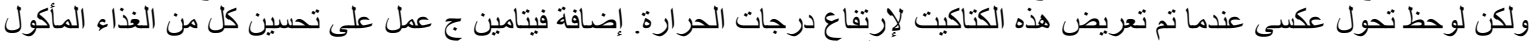

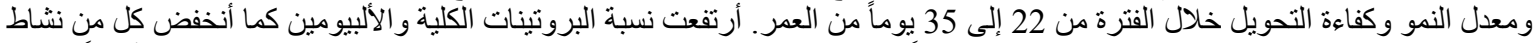

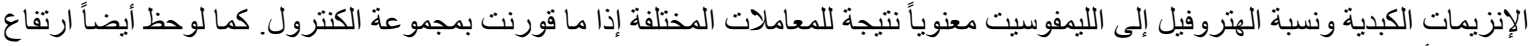

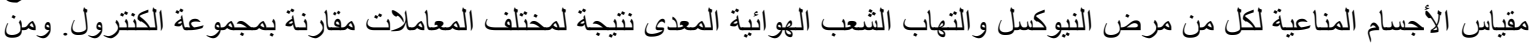

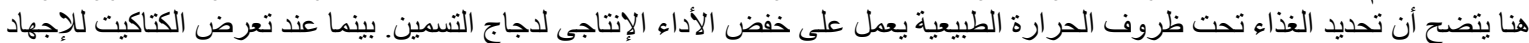

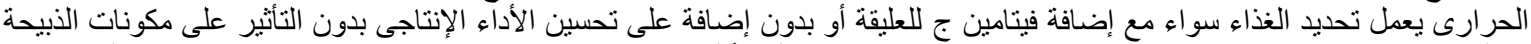

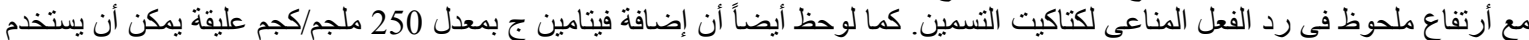
لتخفيف التأثير ات السلبية للإجهاد الحرارى على كل من الأداء الإنتاجى ورد الفعل المناعى لإجاج التئن التسمين. 